\title{
Advisors or Enablers? Bringing Professional Service Providers into the Guiding Principles' Fold
}

\author{
Anita RAMASASTRY $\llbracket * *$
}

\begin{abstract}
After a decade, different businesses adhere to the UN Guiding Principles on Business and Human Rights (UNGPs). Some key commercial entities, however, remain largely outside of the UNGPs universe, including professional service providers (PSPs) who are retained by businesses to provide expert advice and services. These advisors include lawyers, management consultants, architects and others. Some may have specialized units that provide advice on the UNGPs when retained solely for that purpose. But when asked to provide general commercial legal advice, to design a building, or restructure a business, such advisors do not typically appear to apply the UNGPs, to identify negative human rights impacts and tailor their advice in a way that prevents or mitigates such impacts. This article explores the connection between the advice provided by PSPs and negative human rights impacts. It underscores the critical need for these advisors to align their business processes and advisory services with the UNGPs to avoid being enablers of human rights abuses.
\end{abstract}

Keywords: architects, consultants, human rights, lawyers, UNGPs

\section{INTRODUCTION}

A global management consulting firm, McKinsey \& Company (McKinsey), made headlines in the past couple of years for some of the counsel they had given clients that seemingly flew in the face of business respect for human rights. For example, in 2018 and again in 2019, they were called out for their work with the US Department of Immigrations Customs and Enforcement (ICE) for which they made over \$20 million in fees. As part of their proposed reform of ICE's processes, the management consultants proposed spending cuts for food and medical care for immigrants placed in detention while awaiting adjudication of their asylum cases. Even federal agency staff members are reported to have asked McKinsey if saving pennies on medical care and food justified the

II Conflicts of interest: The author declares none.

* University of Washington School of Law, USA. 
human cost. ${ }^{1}$ McKinsey denied the allegations in the NY Times Story, saying that it was focused on trying to improve procurement. ${ }^{2}$ In 2018, McKinsey had ended its contractual relations with ICE saying that the New York Times reporting had 'rightly raised concerns'. ${ }^{3}$ But the implications of a 2019 New York Times investigative report was that the consulting firm had negatively impacted human rights in the name of economic efficiency during its contractual relationship.

Would McKinsey's use of Pillar Two of the UN Guiding Principles on Business and Human Rights (UNGPs) ${ }^{4}$, and the concept of human rights due diligence, have made a difference to its advice? The answer is most likely yes. It would have created a process whereby the company would have identified the negative human rights impacts of its recommendations and then have taken steps to present or mitigate the impacts, possibly through changing its recommendations. In a world where these explicit impacts are not part of consulting business processes, adverse human rights impacts are not considered with the deliberateness called for by the UNGPs. ${ }^{5}$ Interestingly, McKinsey does have a human rights statement, which refers to the UN Global Compact, but which does not mention the UNGPs, the key framework which sets forth the concept of human rights due diligence. ${ }^{6}$

Similar issues arise in other contexts involving professional service providers (PSPs)/ advisors. For example, architects are now confronting the issue of prison design and its connection to torture, and cruel inhumane and degrading treatment. Richard Sperry, the president of Architects/Designer/Planners for Social Responsibility (ADPSR) believes architects should not design prisons. Oher architects have called for a ban on the design of execution chambers. ${ }^{7}$ Lawyers who have served as arbitrators in major international

\footnotetext{
1 Michael Forsythe and Walt Bogdanich, 'McKinsey Ends Work With ICE Amid Furor Over Immigration Policy', New York Times (9 July 2018), https://www.nytimes.com/2018/07/09/business/mckinsey-ends-ice-contract.html (accessed 10 May 2021); Ian MacDougall, 'How McKinsey Helped the Trump Administration Carry Out its Immigration Policies', New York Times (3 December 2019, updated 24 February 2021), https://www.nytimes.com/ 2019/12/03/us/mckinsey-ICE-immigration.html (accessed 10 May 2021).

2 McKinsey and Company, 'Statement on New York Times and ProPublica Article Regarding ICE and CBP' (4 December 2019), https://www.mckinsey.com/about-us/media/mckinsey-statement-on-new-york-times-andpropublica-article-regarding-ice-and-cbp (accessed 10 May 2021).

3 Forsythe and Bogdanich, note 1.

4 United Nations Human Rights Council, 'Guiding Principles on Business and Human Rights: Implementing the United Nations "Protect, Respect and Remedy” Framework', A/HRC/17/31 (21 March 2011), https://www.ohchr.org/ documents/publications/guidingprinciplesbusinesshr_en.pdf (accessed 10 May 2021).

5 UNGP 17 states:
}

In order to identify, prevent, mitigate and account for how they address their adverse human rights impacts, business enterprises should carry out human rights due diligence. The process should include assessing actual and potential human rights impacts, integrating and acting upon the findings, tracking responses, and communicating how impacts are addressed. Human rights due diligence: (a) Should cover adverse human rights impacts that the business enterprise may cause or contribute to through its own activities, or which may be directly linked to its operations, products or services by its business relationships.

6 McKinsey and Company, 'Human Rights Statement', https://www.mckinsey.com/about-us/social-responsibility/ code-of-conduct/human-rights-statement (accessed 10 May 2021).

7 Jerry Adler, 'Architecture and Prison Design', Architectural Record (4 March 2019), https:// www.architecturalrecord.com/articles/13919-architecture-and-prison-reform (accessed 10 May 2021); Michael Kimmelman, 'There's No Reason for an Architect to Design a Death Chamber', New York Times (12 June 2020, updated 15 June 2020), https://www.nytimes.com/2020/06/12/arts/design/architects-prison-death-chamber.html (accessed 10 May 2021). 
investment disputes involving alleged human rights abuses, have been called out for conflicts of interest relating to their ties to corporate interests and their willingness to vigorously pursue cases against States relating to issues of foreign debt, for example, that will cost millions of dollars and deprive people of access to essential services and social and economic rights. ${ }^{8}$

Consulting firms, lawyers, financial advisors, accountants, even architects and real estate brokers are key advisors to the modern transnational corporation. These PSPs are retained for their specialized training and advice. ${ }^{9}$ Within the past decade, different businesses and sectors have engaged in UNGPs implementation. As noted above, many PSPs have actually turned their advising on the UNGPs into a profit-making endeavour. Yet these advisors, while providing critical advice, are not themselves embedding the UNGP framework into their general advisory functions. This is a large gap in the business and human rights (BHR) universe as these advisors are critical intermediaries that could use their leverage to ensure better human rights engagement by their clients, and who may be enabling negative human rights impacts if their advice is not factoring in salient impacts.

In the context of other situations, such as preventing corruption, money laundering and tax evasion, such advisors have often been key partners in wrongdoing and illicit behaviour or willfully blind to the conduct of their clients. Thus, for PSPs, they have an important role to play in advising their clients to avoid money laundering and other types of financial crimes. ${ }^{10}$ In February 2021, the Organisation for Economic Co-operation and Development (OECD) published a report focused on tax and other professionals who enable white collar crimes and tax evasion. ${ }^{11}$ The OECD referred to lawyers, accountants and other service professionals as 'professional enablers', often associated with the secretive offshore finance industry, who 'undermine not only the rule of law, but their own profession'. ${ }^{12}$ Such PSPs also have a role to play in preventing such crimes from taking place, and also the related harm that the underlying criminal conduct has caused, be it human trafficking, or health care fraud. Another term that has been used for professional services firms is 'gatekeepers' in that their services are essential to

\footnotetext{
8 Martin Dietrich Brauch, 'Toward a Code of Conduct for Investment Adjudicators: Can Ethical Standards Salvage ISDS?', Investment Treaty News (20 September 2019), https:/www.iisd.org/itn/en/2019/09/19/toward-a-code-ofconduct-for-investment-adjudicators-can-ethical-standards-salvage-isds-martin-dietrich-brauch/ (accessed 10 May 2021); Corporate Europe Observatory, Profiting from Injustice. How Law Firms, Arbitrators and Financiers are Fuelling an Investment Arbitration Boom (2012), https://corporateeurope.org/en/international-trade/2012/11/profitinginjustice (accessed 10 May 2021).

9 The Merriam Webster online dictionary refers to professional services as a 'service requiring specialized knowledge and skill usually of a mental or intellectual nature and usually requiring a license, certification, or registration', https:// www.merriam-webster.com/legal/professional\%20service (accessed 10 May 2021).

10 See, for example, Financial Action Task Force, 'Money Laundering and Terrorist Financing, Vulnerabilities of Legal Professionals' (2013), https://www.fatf-gafi.org/media/fatf/documents/reports/ML\%20and\%20TF\%20vulnerabilities\% 20legal\%20professionals.pdf (accessed 10 May 2021).

11 OECD, Report, 'Ending the Shell Game: Cracking Down on the Professionals who Enable Tax and White Collar Crimes' (25 February 2021), https://www.oecd.org/tax/crime/ending-the-shell-game-cracking-down-on-theprofessionals-who-enable-tax-and-white-collar-crimes.pdf (accessed 10 May 2021).

12 Ibid. The Bureau of Investigative Journalism, based in the UK, also describe these providers as 'enablers' - allowing crime and misery to occur, while providing advice as to how to hide assets.Bureau of Investigative Journalism, 'The Enablers: Investigating How UK Executives, Lawyers and Advisors are Enabling Oligarchs, Dictators and Criminals Around The World', https://www.thebureauinvestigates.com/projects/the-enablers (accessed 10 May 2021).
} 
achieving a business purpose - whether lawful or not - such as creating an offshore trust, for example. ${ }^{13}$ Law enforcement has focused on gatekeepers as intermediaries who are positioned to deter or prevent illegal activity. ${ }^{14}$

Civil society, human rights organizations and policymakers have not yet turned their gaze to professional services firms as potential enablers of corporate human rights abuses or as critical gatekeepers that are necessary to the execution of business activities that may harm rights holders. To date, such advisors have not been asked to adhere to the UNGPs in the same way that the businesses they advise have been asked to do, by multilateral institutions and national governments. If a client comes to a consulting firm or law firm for other advice, for example, on contract enforcement, or on cost-cutting measures, the advice provided should include an assessment of salient human right impacts alongside other recommendations. When a client seeks the services of a law firm, an architectural firm, or consulting firm, it is unclear when and how human rights screening of a client or project occurs.

It has often taken quite a push in global policy arenas, to get such advisors to play their part in actively preventing and detecting money laundering. It has been a challenge to ensure that they properly screen clients, advise clients and report illegal activity to appropriate law enforcement agents. ${ }^{15}$ The reason? Turning down clients and losing revenue is not a desirable outcome. ${ }^{16}$ Lawyers also are concerned that mandatory reporting governments may conflict with their duty of confidentiality. ${ }^{17}$ Similar inertia may exist when it comes to embracing the UNGPs by PSPs/advisors. What would it look like if a consulting firm had to 'know and show' its adverse human rights impacts arising from its advisory business relationships?

This article explores the lack of engagement by these PSPs in advising their clients to respect human rights. This is, of course, distinct form those consultants and lawyers who have made money peddling general business and human rights advice. This article examines three of these critical advisory roles - management consulting, and the architectural and legal professions, and addresses why engagement with the UNGPs and basic concepts of business 'respect for human rights' should be part of general business advising and preventing harm to rights-holders. Part II of this article examines the current landscape and how and why the UNGPs should apply to these PSPs. The main issue is that companies are relying on external advisors as trusted experts. In such contexts, advisory services can lead to advice or service provision that is harmful

\footnotetext{
13 KL Shepherd, 'Guardians at the Gate: The Gatekeeper Initiative and the Risk-Based Approach for Transactional Lawyers' (2009) 43 Real Property, Trust \& Estate Law Journal 607.

14 Ibid.

15 Chris Ives and Ivaylo Todorov, 'PSPs in the Crosshairs of Regulators', Kroll Web page (29 January 2020), https:// www.kroll.com/en-ca/insights/publications/compliance-risk/professional-service-providers-regulators (accessed 10 May 2021).

16 Sofia Tirini, 'Clients Should Require their Law Firms to Have Robust Compliance Programs', FCPA Blog (27 November 2019), https://fcpablog.com/2019/11/27/clients-should-require-their-law-firms-to-have-robustcompliance-programs/ (accessed 10 May 2021); Thomson Reuters/Ownership Transparency, 'Anti-Laundering Bodies Cite Role of PSPs in Hiding Beneficial Ownership' (24 July 2018), http://ownershiptransparency.com/aml/ anti-laundering-bodies-cite-role-professional-service-providers-hiding-beneficial-ownership/ (accessed 10 May 2021). 17 American College of Trust and Estate Counsel, 'Combating Money Laundering: Lawyers and the FATF's Role', https://www.actec.org/resources/fatf-and-the-lawyers-role/\#3 (accessed 10 May 2021).
} 
to rights-holders. The underlying premise is that the UNGPs and human rights due diligence, when deployed, will lead to more rights-respecting advising, and better outcomes for rights-holders. Part III maps a way forward. As mandatory human rights due diligence is considered in European nations and within the EU itself, regulators need to consider the role of PSPs. Similarly, licensing and accreditation bodies, as well as individual firms and professionals, should consider the larger implications of the UNGPs on their area of service and consider taking steps to embed the UNGPs more fully into their work - not just as a standalone area of advisory service. Part III offers some initial recommendations while recognizing that each profession will be different in terms of how it is regulated and governed, and what ethical and licensing requirements may apply.

\section{Should PSPs Embrace the UNGPs?}

The UNGPs apply to all business entities - this would include professional service firms and providers - as they, too, are businesses. UNGP 14 states that 'the responsibility of business enterprises to respect human rights applies to all enterprises regardless of their size, sector, operational context, ownership and structure'. ${ }^{18}$ Thus, the idea is that they should incorporate the UNGPs as the global authoritative standard on business respect for human rights. For those advisors who operate transnationally, this imperative should be even greater, as the advice provided to clients is about navigating the grey areas in terms of local laws and international human rights.

The 'business' of business and human rights is different from PSPs actively integrating the UNGPs into their processes and client-advisory services across the board. While many PSPs do offer a human rights department or service, the companies that will retain these services are a subset that have decided affirmatively to seek guidance about human rights. What about the rest of the clients? This is very different from an advisor providing holistic advice about the human rights impacts of any business decision. These issues also arise when advising government clients, or public institutions. If the nature of advice provided, as outlined in some of the examples below, does not take into account negative human rights impacts, then providing non-rights compatible guidance, which requires companies or governments to take affirmative steps, itself might be seen as contributing to human rights abuses - rather than just creating a situation of 'linkage'. PSPs provide critical advice - from how to run a business, to how to build a structure, that is critical to a client's operations; ${ }^{19}$ and with that difference comes a potential need to provide access to effective remedy to a person harmed as a result of their advice.

\section{A. Management Consultants}

McKinsey may have found itself in the headlines compared with its competitors because it is perceived as one of the most successful and prestigious consulting firms in the

18 UNGP 14, note 4.

19 UNGP 19, note 4. 
world. ${ }^{20}$ The consulting firm being called out for its business dealings is just an example or case study which should be illustrative for other peer firms. In addition to the ICE controversy, McKinsey has been called out for several other ethical/human rights scandals.

In 2020, McKinsey was criticized for its engagement with the opioid industry and Purdue Pharmaceuticals, the maker of the drug OxyContin, and its connection to opioid addiction in the United States. In a lawsuit filed by the Massachusetts Attorney General, McKinsey was accused of aiding Purdue to 'fuel' the opioid epidemic. McKinsey's consultants, the attorney general alleged, had instructed Purdue on how to 'turbocharge' sales of OxyContin as well as how to counter efforts by drug enforcement agents to decrease opioid usage. ${ }^{21}$

In a 2017 PowerPoint presentation, according to court records, submitted in action on behalf of multiple state attorneys general, McKinsey laid out various options to boost sales. One was to give Purdue's OxyContin distributors a financial rebate for every overdose attributable to prescriptions they sold. The PowerPoint presentation estimated how many customers of companies, including major pharmacy chains, might overdose. The slide forecast that in 2019, for example, approximately 2,484 CVS customers would either overdose or develop some type of opioid use disorder. A rebate of $\$ 14,810$ per 'event' meant that Purdue might lead to CVS receiving approximately $\$ 36.8$ million that year. $^{22}$ McKinsey settled a multistate lawsuit with 47 attorneys general for $\$ 573$ million. ${ }^{23}$ In a December 2020 statement on its website, McKinsey also issued an apology and noted it will take into account larger context of its actions in the future:

Our work with Purdue was designed to support the legal prescription and use of opioids for patients with legitimate medical needs, and any suggestion that our work sought to increase overdoses or misuse and worsen a public health crisis is wrong. That said, we recognize that we have a responsibility to take into account the broader context and implications of the work that we do. Our work for Purdue fell short of that standard. ${ }^{24}$

\footnotetext{
20 Daniel Markowitz, 'How McKinsey Destroyed the Middle Class Technocratic management, No matter how Brilliant, Cannot Unwind Structural Inequalities', The Atlantic (3 February 2021), https://www.theatlantic.com/ ideas/archive/2020/02/how-mckinsey-destroyed-middle-class/605878/ noting that McKinsey serves management at 90 of the world's top 100 companies (accessed 10 May 2021); Sheelah Kolhatkar, 'McKinsey's Work For Saudi Arabia Highlights History of its Unsavory Entanglements', The New Yorker (20 November 2018), https://www. newyorker.com/news/news-desk/mckinseys-work-for-saudi-arabia-highlights-its-history-of-unsavory-entanglements (accessed 10 May 2021).

21 Massachusetts Attorney General, Amended Complaint and Jury Demand, 'Commonwealth of Massachusetts v Purdue Pharma', Superior Court C.A. No, 1884-cv-01808 (BLS2) (21 January 2019), https://www.documentcloud.org/ documents/5715954-Massachusetts-AGO-Amended-Complaint-2019-01-31.html (accessed 10 May 2021); Michael Forsyth and Walt Bogdanich, 'McKinsey Advised Purdue Pharma How to "Turbocharge" Opioid Sales, Lawsuit Says' New York Times (1 February 2021), https://www.nytimes.com/2019/02/01/business/purdue-pharma-mckinseyoxycontin-opiods.html (accessed 10 May 2021).

22 Forsyth and Bogdanich, ibid.

23 Brian Mann, 'Consulting Giant McKinsey to Settle Opioid Claims for 573 Million', Morning Edition, National Public Radio (4 February 2021), https://www.npr.org/2021/02/04/963864747/consulting-giant-mckinsey-to-settleopioid-claims-for-573-million (accessed 10 May 2021).

24 McKinsey \& Company, 'Statement on its Past Work with Purdue Pharma' (5 December 2020), https:// www.mckinsey.com/about-us/media/mckinsey-statement-on-its-past-work-with-purdue-pharma (accessed 10 May 2021).
} 
Of course, this apology misses the point. If a consultant factors in the human rights impacts of its initial proposals, it would have focused on the harm to patients from such business models and considered mitigation and prevention strategies. The UNGPs are precisely about taking into account the 'broader context and implications' of their work which includes human rights.

McKinsey has found itself in hot water in other instances relating to business relationships with governments. In 2015, McKinsey prepared what it has described as an internal report that measured the public reception of the Kingdom of Saud Arabia's economic austerity programme in 2015. The question of whether McKinsey was retained by Saudi Arabia in relation to these general issues is unclear. The McKinsey internal report found that the austerity measures got double the volume of coverage on Twitter as they did in conventional news outlets. The Twitter reactions were described as generally more negative. McKinsey noted in its report that three Twitter accounts drove the social media conversation, and identified the names of those users. ${ }^{25}$ After the report was issued, the user of one of the accounts was arrested, and another user reported that his telephone was hacked and that two of his brothers were arrested. The third account, which was anonymous, was shut down. ${ }^{26}$ McKinsey's response was that it was horrified by the fact that the report could have been used to identify and detain persons:

We were never commissioned by any authority in Saudi Arabia to prepare a report of any kind or in any form to identify critics. In our work with governments, McKinsey has not and never would engage in any work that seeks to target individuals based on their views. The document in question was a brief overview of publicly available information looking at social media usage. It was not prepared for any government entity. Its intended primary audience was internal. We are horrified by the possibility, however remote, that it could have been misused in any way. At this point, we have seen no evidence to suggest that it was misused, but we urgently investigating how and with whom the document was shared. ${ }^{27}$

In March 2021, McKinsey was sued by one of the persons identified in the McKinsey document. Omar Abdulaziz is suing McKinsey in the U.S. for allegedly outing him to Saudi authorities as one of the Twitter critics. Abdulaziz sought asylum in Canada in 2013, where he was studying. He said McKinsey identified him as one of three social media critics of Saudi Arabia in its report. His complaint alleges that McKinsey either 'furnished' the report to the Saudi Crown Prince or his agents, or 'allowed' them to access it. ${ }^{28}$ His scholarship

\footnotetext{
25 Katie Benner, Mark Mazzetti, Ben Hubbard and Mike Isaac, 'Saudi's Image Makers: A Troll Army and a Twitter Insider', New York Times (20 October 2018), https://www.nytimes.com/2018/10/20/us/politics/saudi-image-campaigntwitter.html (accessed 10 May 2021).

26 Michael J de la Merced, 'McKinsey Takes Heat for its Saudi Work', New York Times Deal Book (22 October 2018), https://www.nytimes.com/2018/10/22/business/dealbook/mckinsey-saudi-dissidents.html (accessed 10 May 2021).

27 McKinsey \& Company, 'Response to New York Times Article of 20 October 2018', Twitter post (20 October 2018), https://twitter.com/mckinsey/status/1053838356826808320?s=21 (accessed 10 May 2021).

28 Danya Hajjaji, 'Exiled Saudi Dissident Sues McKinsey in U.S. for Outing Him to MBS', Newsweek (10 February 2021), https://www.newsweek.com/exiled-saudi-dissident-sues-mckinsey-us-outing-him-mbs-1568226 (accessed 10 May 2021).
} 
from Saudi Arabia has been revoked. His complaint also alleges that Saudi authorities have tortured and detained members of his family as well as friends and associates in an effort to put pressure on him. The lawsuit alleges Abdulaziz's brother and friends have been 'waterboarded' and electrocuted and that other family members have been subjected to travel bans. ${ }^{29}$ McKinsey notes that a similar claim was previously dismissed in California in a lawsuit filed against Twitter and McKinsey and that the company will vigorously defend itself against the lawsuit. ${ }^{30}$ The current action has been removed to federal district court in New York and McKinsey has moved to have the case dismissed. ${ }^{31}$

Would a human rights assessment have made a difference in terms of McKinsey's actions? If the consultants had stopped to think about what such a report and compilation might do, it might have chosen not to prepare such a report or to eliminate the reference to specific Twitter users. Again, it is hard to reverse-engineer situations to see how an impact assessment might lead to a different outcome, but proactive advising that builds in human rights decision-making is better than cleaning up after someone's life is put in jeopardy. McKinsey may be absolved of legal liability, but its actions trigger issues relating to access to remedy under UNGP Pillar III if the report creation or circulation contributed to serious human rights abuses. While McKinsey is an adherent to the UN Global Compact, it does not, however, reference the UNGPs or the concept of human rights due diligence in its human rights policy. ${ }^{32}$ The concept of do no harm would mean that a consulting firm would identify those risks to which is might be linked (or cause or contribute to) and identify prevention and mitigation strategies, or change the nature of the advice given. In each of the situations, the question of how human rights due diligence might make a difference is the relevant question.

Other consulting firms have been criticized by civil society groups for their work in Saudi Arabia including Boston Consulting Group and Oliver Wyman. They have been called out for their advisory work on the NEOM Megacity project and their linkage to adverse human rights impacts including the forceable eviction of a nomadic Bedouin tribe, the al-Huwaitat tribe. ${ }^{33}$ These two firms worked alongside McKinsey on the NEOM project. In April 2020, activist Abdul-Rahim al-Howeiti, a land rights defender, was killed by Saudi security forces when protesting against his community's forced expulsion from their land.

A group of civil society organizations wrote to the three consulting firms to ask them to divest from the project and also made additional recommendations for further action including a public condemnation of the killing as well as engagement with the local

\footnotetext{
29 Ibid.

30 Omar Abdulaziz, Plaintiff v Twitter, Inc, McKinsey \& Co, and Does 1-10 Inclusive, https://dockets.justia.com/ docket/california/candce/3:2019cv06694/349982 (accessed 10 May 2021); Priscilla DeGregory, 'Saudi Dissident Sues After Report Outs Him as Influential Opponent of Regime', New York Post (9 February 2021), https://nypost.com/2021/ 02/09/saudi-dissident-sues-after-being-outed-as-critic-of-regime/ (accessed 10 May 2021).

31 See Filings in Abdulaziz v McKinsey \& Company, Inc. et al, https://www.pacermonitor.com/public/case/38297140/ Abdulaziz_v_McKinsey_Company,_Inc_et_al (accessed 10 May 2021).

32 McKinsey \& Co Human Rights Statement, note 6.

33 MENA Rights Group, 'NGOs Call on Management Consulting Firms Involved in Saudi Arabia's NEOM Project to Publicly Condemn Human Rights Violations Accompanying It' (2 June 2020), https://menarights.org/en/articles/ngoscall-management-consulting-firms-involved-saudi-arabias-neom-project-publicly-condemn (accessed 10 May 2021).
} 
community. ${ }^{34}$ Their letter sets forth expectations regarding the consulting firms and how they should demonstrate respect for human rights under the UNGPs. The Business and Human Rights Resource Centre (BHRRC) followed up with the three consulting firms to ask for their responses.

McKinsey responded and stated that it adheres to the UN Global Compact and also expects its clients to adhere to its professional code of conduct. The response does not directly address the issues raised by the BHRRC or the NGOs and does not mention the UNGPs. ${ }^{35}$ Boston Consulting also replied with a more generic response saying that in such projects it adheres to international standards including those set forth by the World Bank and the International Finance Corporation for such projects. The response mentions neither the UNGPs nor human rights. ${ }^{36}$ Oliver Wyman did not respond.

This is not to say that consulting firms or auditing firms do not have more explicit policies. KPMG, for example, notes that it has a human rights statement and complies with the UNGPs in its policies and procedures. ${ }^{37}$ One can scour the web, however, as well as academic literature, and it is difficult to find publicly available literature that talks about the ethical obligations of consultants to provide their clients with human rights advising. One does, however, find plenty of brochures advertising tailored human rights services. The example from McKinsey's recent controversies are case studies in how a human rights-based approach could help avoid the harms that may have ensued - from budget cuts linked to socio-economic rights, to arbitrary detention and torture.

\section{B. Architects}

Architects may find themselves implicated in human rights abuses in a multiplicity of ways. ${ }^{38}$ First, they may serve a client, that itself engages in systemic human rights abuses - as part of an authoritative regime, for example. Serving such clients, especially if a commission is one that is a 'white elephant' stadium or palace, may drain local coffers, and deprive public of their social and economic rights. ${ }^{39}$ In addition, they may be asked to build structures which themselves are sites of human rights abuse - such as prisons and detention centres.

In such situations, the use of the UNGPs should cause the architect to ask questions and engage in human rights due diligence to understand if the project is indeed respecting of

\footnotetext{
34 Ibid

35 'McKinsey \& Company's response received 26th June 2020 re killing of land defender Abdul-Rahim Al-Howeiti at NEOM, Saudi Arabia', Business and Human Rights Resource Centre website (26 June 2020), https:// media.businesshumanrights.org/media/documents/files/documents/Response_Mckinsey_and_Company_260620.pdf (accessed 10 May 2021).

36 'Boston Consulting Group's Response received 30 April 2020 re killing of land defender Abdul-Rahim Al-Howeiti at NEOM, Saudi Arabia', Business and Human Rights Resource Center website (13 May 2020), https://www.businesshumanrights.org/en/latest-news/boston-consulting-group-re-killing-of-land-defender-abdul-rahim-al-howeiti-at-neomsaudi-arabia/ (accessed 10 May 2021).

37 KPMG, 'Business and Human Rights Statement', https://home.kpmg/xx/en/home/about/who-we-are/governance/ business-and-human-rights-statement.html (accessed 10 May 2021).

38 Graeme Bristol, 'Architecture and Human Rights' in Thomas Cushman (ed.), The Handbook of Human Rights (London: Routledge, 2013), 659.

39 Adam Gopnik 'The Field Guide to Tyranny', The New Yorker (16 December 2019), https://www.newyorker.com/ magazine/2019/12/23/the-field-guide-to-tyranny (accessed 10 May 2021).
} 
human rights. Then there are projects which will have human rights abuse impacts by virtue of the project and its scope. An example of this was construction for the Qatar World Cup. According to various reports, there were significant worker deaths tied to the 2022 World Cup construction as early as 2013. ${ }^{40}$ Architect Zaha Hadid, for example, was called out publicly for her role in designing Qatar's new Al Wakrah Stadium for the 2022 World Cup. ${ }^{41}$ Hadid, an Iraqi-born architect based in the UK, noted that the issue of worker deaths in stadium construction was a matter for the Qatari government, not for architects. ${ }^{42}$ Qatar has responded to international calls for improvement of worker welfare and launched a variety of initiatives focused on labour rights subsequent to pressure from external stakeholders and organizations. Recently, however, a variety of players, teams and human rights groups have issued a renewed call for a boycott of the 2022 men's World Cup due to what is perceived to be a high rate of worker deaths. ${ }^{43}$ The UNGPs speak about the use of 'leverage' by businesses when they are linked to human rights abuses. Leading architects and their firms have influence and can exercise leverage when agreeing to design a major site, and to oversee its construction.

The American Institute of Architects (AIA) does have a requirement within its ethics code that members 'uphold human rights in all their professional endeavors' ${ }^{44}$ Until 2020, the AIA Code of Ethics had one rule connected to its human rights standard - and this related to discrimination and harassment. Anti-discrimination and prevention of harassment are key human rights concerns but some architects note that the AIA code ignored other situations where human rights impacts were apparent, including the construction of detention facilities, execution chambers and prisons with solitary confinement spaces.

The AIA's human rights commitment has not deterred architects from assisting clients that want designs that may lead to significant human rights abuses. ${ }^{45}$ Only in late 2020, did the AIA modify its ethics code to prohibit members from knowingly designing spaces intended for execution or torture, including prolonged periods of solitary confinement. ${ }^{46}$ While the sanction for non-compliance is expulsion from the AIA, the goal is not to cause architects to

\footnotetext{
40 International Trade Union Confederation, Special Report 'The Case against Qatar: Host of the 2022 World Cup' (March 2014), https://www.ituc-csi.org/IMG/pdf/the_case_against_qatar_en_web170314.pdf (accessed 10 May 2021); Wesley Stephenson, 'Have 1200 World Cup Workers Really Died in Qatar?', BBC News (6 June 2014), https://www.bbc. com/news/magazine-33019838 (accessed 10 May 2021).

41 Beatrice Thomas, “'It's not my duty” to push Qatar Labour Rights says Zaha Hadid', Arabian Business (5 March 2014), https://www.arabianbusiness.com/-it-s-not-my-duty-push-qatar-labour-rights-says-zaha-hadid541578.html\#.Uyqss4UVeT8 (accessed 10 May 2021).

42 James Riach, 'Zaha Hadid Defends Qatar World Cup Role Following Migrant Worker Deaths', The Guardian (25 February 2014), https://www.theguardian.com/world/2014/feb/25/zaha-hadid-qatar-world-cup-migrant-workerdeaths (accessed 10 May 2021).

43 Don Riddell and George Ramsay, 'Boycotting the 2022 FIFA World Cup in Qatar would be a "Big Mistake" Says Belgium Manager Roberto Martínez', CNN (26 March 2021), 'https://www.cnn.com/2021/03/26/football/fifa-worldcup-qatar-roberto-martinez-spt-intl/index.html (accessed 10 May 2021).

44 American Institute of Architects, Code of Ethics and Professional Conduct 2020, https://content.aia.org/sites/ default/files/2020-12/2020_Code_of_Ethics.pdf (accessed 10 May 2021).

45 Raphael Sperry, 'Discipline and Punish: The Architecture of Human Rights', Architectural Review (31 March 2014), https://www.architectural-review.com/essays/discipline-and-punish-the-architecture-of-human-rights (accessed 10 May 2021).

46 The Editors, 'The AIA Bans Designing Spaces Intended for Execution, Torture', Surface Magazine (14 December 2020), https://www.surfacemag.com/articles/aia-bans-designing-spaces-for-execution-torture/ (accessed 10 May 2021).
} 
lose their professional membership, but rather to have more firms use 'leverage' by refusing to take on commissions connected to significant human rights abuses. Many other major architectural associations and codes, however, do not yet refer to human rights. ${ }^{47}$

ADPSR have launched major campaigns focused on the human rights responsibilities of architects. They led the campaign for the AIA focused on design for torture and killing. ADPSR also has campaigns focused on rejecting contracts for building the Trump administration's border wall in the US along the southern border, and also against built environment projects that are connected to racial discrimination. ${ }^{48}$ ADPSR does not make reference to the UNGPs on its website but does mention the Universal Declaration of Human Rights. In its campaign focused on ending construction linked to torture and execution, ADPSR did note that: 'AIA members deserve more detailed guidance on how they can reconcile client requests for those project types [prison construction] with a generalized responsibility to uphold human rights'.

The UNGPs could be a useful starting point where architects can require human rights due diligence form their clients, and engage in their own human rights due diligence and impact assessments as part of any project. ADPSR further states: 'with regard to architecture, the larger firms that are prepared to design complex supermax prisons are generally AIA member firms, and they are typically offer may other kinds of prison designs. We think they are in a much stronger position to assist their justice system clients in making sure their projects to not violate human rights standards with the ethics code amendment in place'. ${ }^{49}$ Again, human rights impact assessments/due diligence would allow architects to identify and propose alternatives to clients that could prevent or mitigate negative human rights impacts.

The Institute for Human Rights and Business (IHRB) is the first business and human rights organization to focus exclusively on the 'built environment' and acknowledges that 'architecture and design have significant potential to advance human rights, including the rights to non-discrimination, and to physical and mental health. But lack of awareness or commitment as well as budget and other constraints can also result in adverse impacts on the rights of individuals and communities including the elderly, low income, and marginalized groups'. IHRB's 2019 Report, 'Dignity in the Built Environment', focuses on the major role that architects as well as other professionals in the real estate sector have to play in the area of human rights: '[P]rivate sector actors have significant influence across the built environment lifecycle, and can either advance or impede the realization of human rights. Real estate represents almost $60 \%$ of the value of all global assets ... And architecture plays a defining role in the fabric of the built environment'.

IHRB makes the case and notes that architects need to take affirmative steps to embrace respect for human rights including:

- Design with the rights of vulnerable and marginalized groups and neighbouring areas in mind;

\footnotetext{
47 Sperry, note 45.

48 Architects/Designers/Planners for Social Responsibility (ADPSR), 'Activism', ADPSR website https:// Www.adpsr.org/activism (accessed 10 May 2021).

49 Ibid, 'FAQ about human rights', https://www.adpsr.org/more human (accessed 10 May 2021).
} 
- Engage local communities in a meaningful way from the outset of any project and throughout its lifecycle;

- Take the human rights record of clients into account when deciding to accept a contract and use any leverage over clients proactively to advance human rights; and

- Support policy initiatives that strengthen dignity in the built environment. ${ }^{50}$

Architects have a critical role to play as experts and need to embed human rights thinking and processes in their work. ADPSR echoes this same theme and also believes that in some circumstances, refusal to engage with projects that may be per se violative of human rights (e.g., building execution chambers), will be an exercise of leverage akin to physicians' refusal to participate in capital punishment/execution.

\section{Lawyers}

Lawyers have a critical role to play as external counsel to companies. They provide advice across many different functions - from protection of intellectual property rights, to contract drafting and enforcement, to mergers and acquisition. At present, the main way in which law firms take human rights and the UNGPs on board is through specialized practice groups, which provide advice to clients who are seeking guidance related to human rights, and more focused topics such as modern slavery, where legislation in jurisdictions such as the UK, Australia and California have required companies to report on human rights or anti-trafficking due diligence in their operations. Chambers \& Partners, a directory of 'top lawyers' publishes annual rankings of law firms and lawyers that advise on business and human rights in global markets. ${ }^{51}$

Lawyers have not been called out actively for their connection to corporate clients that may have poor human rights records. ${ }^{52}$ This is to some extent because of the principle that everyone is entitled to legal advice and representation, including dictators or war criminals. There is of course, a distinction between representing someone accused of a crime and representing a corporate client or repressive regime in a business deal. Lawyers have been implicated in controversies that have strong connections to human rights. ${ }^{53}$ For example, lawyers have been criticized for their own ethical advising and positions relating to kleptocrats, oligarchs and others, who use lawyers and other PSPs to help launder their money via offshore trusts and shell companies. These include the leader of

\footnotetext{
50 Institute for Human Rights and Business, Report, 'Dignity by Design: Human Rights and the Built Environment' (2019), https://www.ihrb.org/uploads/reports/IHRB_Dignity_by_Design_Human_Rights_and_the_Built_Environment_ Lifecycle_July2019.pdf (accessed 10 May 2021).

51 Chambers \& Partners, 'Business \& Human Rights Law in Global Market Leaders Legal Rankings', https:// chambers $. c o m / g u i d e / g l o b a l$ ?publicationTypeGroupId=2\&practiceAreaId=2708\&subsectionTypeId=1\&locationId= 20987 (accessed 10 May 2021).

52 David Allen Green, 'Should a Lawyer Ever Refuse to Act in an Unpleasant Case', Prospect Magazine (3 March 2021), https://www.prospectmagazine.co.uk/up-front/lawyer-unpleasant-cases-refuse-clients-cab-rank-rule (accessed 10 May 2021); Alex Pareene, 'Neil Katyal and the Depravity of Big Law', The New Republic (8 December 2020), https://newrepublic.com/article/160481/neal-katyal-depravity-big-law (accessed 10 May 2021).

53 Erin Quinn, 'U.S. Lobbying/PR Firms give Human Rights abusers a Friendly Face', Slate/Center for Public Integrity (17 December 2015), https://publicintegrity.org/politics/u-s-lobbying-pr-firms-give-human-rights-abusers-a-friendlyface/ (accessed 10 May 2021).
} 
Equatorial Guinea and his son Teodorin, who retained US lawyers to help shield assets stolen from the Equatorial Guinean treasury. ${ }^{54}$

Kleptocrats steal public finances, leaving national treasuries depleted and people living in poverty, deprived of basic social and economic rights, and often subject to human rights abuses that exist in repressive or authoritarian regimes. In these situations, lawyers have often been labelled as 'enablers'. Global Witness, a leading anti-corruption NGO, was able to record lawyers on an undercover investigation, appearing willing to help a potential 'client' to move suspect money to the US. ${ }^{55}$ At times, they have opposed the extension of more stringent regulations to prevent money laundering, to the legal profession. ${ }^{56}$

But the role of the UNGPs is not about a lawyer or law firm refusing to provide advice, but rather focusing on how advice is provided and the way in which the anticipation of negative human rights impacts could and should be part of the guidance to a client. ${ }^{57}$ To date, bar associations at the national, regional and global levels have embraced the UNGPs as part of a lawyer's ethical and professional responsibility. This is an important first step in terms of normative developments. The key, however, will be translating this into implementation such that licensing bodies for lawyers will similarly focus on human rights as an important part of professional requirements. While major corporate law firms may be aware of the UNGPs this does not mean that every lawyer or associate within such practices are cognizant of BHR discourse.

The UNGPs calls on law firms as business entities, to respect human rights, both in their own operations and through their business relationships, which includes their relationships with clients. As the American Bar Association (ABA) has recognized, law firms' responsibility to respect human rights extends to adverse human rights impacts that are directly linked to a law firm's services through a client relationship. The ABA was the first bar association to endorse the UNGPs in 2012 through its House of Delegates. ${ }^{58}$ The ABA Center for Human Rights in its report supporting the ABA resolution endorsing the UNGPs connected the duty of a lawyer to provide independent and candid advice under ABA Model Rule of Professional Conduct 2.1

\footnotetext{
54 Tutu Alicante, 'Combating Transnational Authoritarian Kleptocracy: Cracking Down on Western Professional Enablers', Just Security Blog (19 April 2021), https://www.justsecurity.org/75736/combating-transnationalauthoritarian-kleptocracy-cracking-down-on-western-professional-enablers/ (19 April 2021).

55 Global Witness, 'Undercover in New York', https://www.globalwitness.org/shadyinc/ (accessed 10 May 2021); Louise Story, 'Report Describes Lawyers Advice on Moving Suspect Funds into the US', New York Times (1 February 2016), https://www.nytimes.com/2016/02/01/us/report-describes-lawyers-advice-on-moving-suspect-funds-into-us. html (accessed 10 May 2021).

56 Alexander Cooley and Casey Michael, 'U.S. Lawyers Are Foreign Kleptocrats' Best Friends', Foreign Policy (23 March 2021), https://foreignpolicy.com/2021/03/23/u-s-lawyers-are-foreign-kleptocrats-best-friends/ (accessed 10 May 202). Jonathan Wolf, 'Ask Why ABA Opposes Bipartisan Anti-Money Laundering Rules Before Renewing Your Membership', Above the Law Blog (9 December 2020), https://abovethelaw.com/2020/12/ask-why-aba-opposesbipartisan-anti-money-laundering-rules-before-renewing-your membership/ (accessed 10 May 2021); Letter from ABA President Judy Perry Martinez to US House of Representatives in Opposition to H.R. 2513, the Corporate Transparency Act of 2019 (22 October 2019), https://www.americanbar.org/content/dam/aba/administrative/government_affairs_ office/final-letter-to-house-opposing-2513.pdf?logActivity=true (accessed 10 May 2021).

57 David Kinley, 'Lawyers, Corporations and International Human Rights Law' (2003) 25 The Company Lawyer 298.

58 ABA House of Delegates Resolution No. 109 (January 2012), https://abanow.org/2012/01/2012mm109/ (accessed 10 May 2012); Debra Cassens Weiss, 'BA House of Delegates Considers Human Rights Responsibilities of Lawyers', ABA Journal (6 February 2012), https://www.abajournal.com/news/article/aba_house_considers_human_rights_ responsibilities_of_corporations/ (accessed 10 May 2021).
} 
with advising about human rights. The rule's commentary notes that 'moral and ethical factors impinge on most legal questions and may decisively influence how the law will be applied'. The report expressly links rule 2.1 of the ABA Model Rules to UNGP $13 .{ }^{59}$

The New York City Bar Association has supported this interpretation through a statement it recently issued in 2020, via its working group on business and human rights. In its recent statement, the working group Affirm[s] (1) that the fulfilment by members of the legal profession in New York City, and beyond, of their duties to serve as an advisor to their clients, as set forth in Rule 2.1 of the New York Rules of Professional Conduct, includes consideration of corporate responsibility to respect human rights, environmental sustainability, and the rule of law; and (2) that the UNGPs do not abridge specific and legally binding professional responsibilities of lawyers, including the duties of independence, confidentiality, and the protection and pursuit of a client's legitimate interests, within the bounds of the law. ${ }^{60}$

According to John Sherman, an advisor to John Ruggie who has written extensively on lawyering and the UNGPs, UNGP 19 and ABA Model Rule 2.1 should be read in tandem. ${ }^{61}$ As Sherman notes, both require a lawyer's advice to be more than advice on the black letter law. Lawyers should propose to clients how to achieve their goals in a way that respects human rights. Ethics codes from foreign jurisdictions, including Canada, the European Union, and Japan, do reference key human rights concepts as a component of ethical law practice. ${ }^{62}$

Sherman notes that such situations call for creative lawyering. For example, in 2003, British Petroleum (BP), the operator of the BTC pipeline in the Caucasus region of Central Asia, encountered NGO complaints that investment stabilization clauses in the project's contracts with host governments would prevent the governments from enacting new legislation to protect human rights. In response, BP negotiated with Amnesty International a human rights undertaking that would allow for evolving national human rights protections and stopped BP from raising certain claims against the government. ${ }^{63}$ Ruggie built on this example in his report on Principles for Responsible Contracting, a guide for lawyers negotiating long-term investment contracts that have significant human rights impacts. ${ }^{64}$ Sherman has also pointed out that the UNGPs remind lawyers of the need to advise clients on legal liability issues that arise from a company's potential complicity in international crimes and gross human rights abuses. ${ }^{65}$ UNGP 23 (c) states that companies should treat the risk of causing or contributing to gross human

\footnotetext{
59 AFID, Guide for the Legal Profession, note 54; Martha F Davis, 'Human Rights and the Model Rules of Professional Conduct: Intersection and Integration' (2010) 42 Columbia Human Rights Law Review 157-186.

60 New York City Bar Association, 'Policy Statement of the New York City Bar's Business and Human Rights Working Group' (June 2020), http://documents.nycbar.org/files/Working_Group_on_Business_and_Human_Rights_ Policy_Statement.pdf (accessed 10 May 2021).

61 John F Sherman III, 'Professional Responsibility of Layers under the UN Guiding Principles' (April 2012), https:// shiftproject.org/professional-responsibility-of-lawyers-under-the-guiding-principles/ (accessed 10 May 2021).

62 Davis, note 59.

63 BTC Human Rights Undertaking (22 September 2003), https://subsites.bp.com/caspian/Human\%20Rights\% 20Undertaking.pdf (accessed 10 May 2021).

64 Sherman, note 61.

65 Ibid.
} 
rights abuses, such as torture, genocide or murder, as a legal compliance issue wherever they operate.

In 2015, the International Bar Association (IBA) also issued guidance for lawyers and bar associations on business and human rights. ${ }^{66}$ The IBA, as well as other national and local bar associations, have emphasized how the UNGPs are intrinsically linked to codes of professional ethics and responsibility. The IBA makes it clear that law firms, as business enterprises, have their own responsibility to respect human rights. In a similar manner to the companies they advise, law firms are asked to commit to respecting internationally recognized human rights, assess the firm's potential human rights impacts (including the firm's employment practices, supply chain, and the legal advice and services it renders), and take action to limit its involvement in human rights impacts.

In 2013, Advocates for International Development (A4ID), based in the UK, published useful guidance for lawyers on the UNGPs and the legal profession that examines a variety of codes of professional conduct around the world, and examines how providing advice on the UNGPs is consistent with lawyers' ethical obligations in different ways. The A4ID guide notes that the UNGPs should be used as a tool by lawyers when screening clients, providing advice and also seeking to terminate client relationships. The guide also examines impediments to use of the UNGPs, such as client confidentiality, which might appear at odds with the 'know and show' tenet of the UNGPs relating to adverse human rights impacts to which a client may cause, contribute or be directly linked. ${ }^{67}$ While many bar associations have explored and affirmed the role of the lawyer and legal profession in advising clients in a manner consistent with the UNGPs, some bar associations have been reluctant to take this position. The German Bar Association has noted that as lawyers are independent legal advisors, it would violate a lawyer's duties of loyalty and confidentiality to provide advice that incorporated the UNGPs. ${ }^{68}$

The larger challenge will be to see how bar associations and licensing/disciplinary bodies interpret lawyers' duties to include providing advice on the UN GPs. The IBA's guidance for bar associations relates to how to further embed the UNGPs into the work of the legal profession. The IBA guidance notes that 'individual bar associations may wish to consider whether, and the extent to which, their own professional codes of conduct prevent, permit, encourage or require lawyers to take the risks of human rights impacts into account in their advice to business clients'. ${ }^{69}$

To date, lawyers as a group are not embracing human rights as part of their advisory function. Classes on professional responsibility in law school do not touch upon the UNGPs. The idea of ensuring advice to clients that engenders respect for human rights exists in terms of high level guidance but has not found its way into day-to-day firm practice and engagement As lawyers begin to explore the ways in which they can and

\footnotetext{
66 International Bar Association (IBA), 'Practical Guide on Business and Human Rights for Business Lawyers' (London: IBA, 28 May 2016), https://www.ibanet.org/MediaHandler?id=D6306C84-E2F8-4C82-A86F93940D6736C4 (accessed 10 May 2021).

67 Advocates for Internarial Development (A4ID), 'The UN Guiding Principles on Business and Human Rights: A Guide for the Legal Profession' (2013), http://www.a4id.org/wp-content/uploads/2016/04/A4ID-Business-andHuman-Rights-Guide-2013-web.pdf (accessed 10 May 2021).

68 Ibid, 353.

69 IBA Guidance, note 66.
} 
should advise on the UNGPs, it is clear that there is more 'hard law' on which to advise, from supply chain transparency laws designed to prevent modern slavery, to laws focusing on trade and export of conflict commodities such as conflict minerals, and in the EU and Europe, laws focused on mandatory human rights due diligence, connected to Pillar II of the UNGPs. ${ }^{70}$ There may become a new compliance advisory function, for which both external as well as in-house counsel will need to embrace human rights advising as part of general commercial practice. ${ }^{71}$

\section{BRINGING PSPS INTO THE UNGPS FOLD}

Consumers are not the answer when it comes to service providers. While they might be able to boycott a retail company who has forced labour in its supply chain and stop buying chocolate, sneakers or computers - individual members of the public are unlikely to ever need a transnational law firm, a management consultant or a global prizewinning architect to help them out directly - hence no leverage. So what is the answer? How can PSPs be seen as advisors who advise on the UNGPs and not as enablers of human rights abuses? This will take a multi-faceted approach and a recognition that experts who provide professional guidance are equally bound by the UNGPs.

\section{A. Ensuring that Regulatory Regimes Expressly Apply to PSPs}

As legislatures continue to enact mandatory human rights due diligence and modern slavery laws, explicit reference needs to be made to PSPs as having explicit compliance obligations under new legislation. ${ }^{72}$ Some PSPs, such as the big four auditing firms, are already active in the policy arena, on topics such as transnational labour governance. They are there advocating as experts who advise companies on specific issues - not engaging on how their own industry should embrace requirements to respect human rights as part of an overall business model. ${ }^{73}$

Policymakers and civil society advocates can learn from the campaign to address the role of service professionals in the fight against corruption. Policymakers have had to document the connection between lawyers, accountants and other professionals who have

\footnotetext{
70 Steve Richman, 'Ethical Issues for Business Lawyers under the United Nations Guiding Principles' (2017-18) 51 The International Lawyer 423

71 Michal K Addo, 'Is Business and Human Rights Suitable for the Compliance Function?', University of Chicago Law Review online (7 January 2020), https://lawreviewblog.uchicago.edu/2020/01/07/is-business-and-human-rightssuitable-for-the-compliance-function-by-michael-k-addo/ (accessed 10 May 2021); John F Sherman III, 'The Corporate General Counsel Who Respects Human Rights' (5 March 2021), accepted for publication in Legal Ethics Journal, current version available at https://ssrn.com/abstract=3624331 (accessed 10 May 2021).

72 See Business and Human Rights Resource Centre, 'Mandatory Human Rights Due Diligence Portal', https:// www.business-humanrights.org/en/big-issues/mandatory-due-diligence/ (accessed 10 May 2021); EU Parliament Briefing, 'Towards a Mandatory EU System of Due Diligence for Supply Chains' (October 2020), https://www. europarl.europa.eu/RegData/etudes/BRIE/2020/659299/EPRS_BRI(2020)659299_EN.pdf (accessed 10 May 2021).

73 Luc Franzen and Genevieve LeBaron, 'Big Audit Firms as Regulatory Intermediaries in Transnational Labor Governance' (2019) 13 Regulation and Governance 216, https://onlinelibrary.wiley.com/doi/full/10.1111/rego.12224 (accessed 10 May 2021); Samantha White, 'The Accountant's Role in Human Rights Due Diligence', Financial Management (19 July 2016), https:/www.fm-magazine.com/news/2016/jul/accountants-role-in-human-rights-duediligence-201614852.html (accessed 10 May 2021).
} 
been identified as critical links in facilitating money laundering and corruption. Two international bodies charged with combating financial crime issued a report in 2018 outlining the role lawyers, accountants and other 'professional intermediaries' actually play in helping to hide the true, or 'beneficial' owners of shell companies and other entities criminals use to disguise their assets. The report was a collaborative effort by the global anti-money laundering group, the Financial Action Task Force (FATF) and the Egmont Group of national Financial Intelligence Units. ${ }^{74}$

Their goal was to document the tangible role that professional intermediaries designated non-financial businesses and professions - play in hiding the true ownership of legal entities. The report decried the fact that many countries still have not issued rules requiring these advisors to report suspicious activity. The report called on governments to do more to educate relevant professionals regarding the money laundering potential of the services they provide because a number of case studies suggested unwitting involvement or wilful blindness.

The ABA has held mixed views on further regulation of the legal profession as gatekeepers. In 2010, it issued voluntary good practice guidance for the legal profession. ${ }^{75}$ It has repeatedly opposed anti-money laundering legislation in the US that would have expanded duties for lawyers citing ethical obligations as well as procedural arguments. These arguments, however, may mask a larger objection which is that supporting such legislation would be bad for business and revenue generation. While it has taken more than two decades for regulators to actively tackle the role of PSPs in the fight against money laundering, it may take just as long to address the role of business lawyers in preventing human rights abuses. The challenge is to ensure that any binding human rights due diligence obligations include clear guidance as to how such regulations apply to PSPs.

\section{B. The Role of Licensing Bodies and Professional Associations}

Professional licensing bodies will have key roles to play in ensuring that where existing licensing requirements and professional code of conduct conflict are silent, that they should be revised to take into account the UNGPs. To the extent that a licensing function is retained by a public or state authority, this should be part of the state duty to protect in Pillar I of the UNGPs. This can also be highlighted in new generations of national action plans on business and human rights which can emphasize the critical role of PSPs who should commit to respect for human rights under Pillar II. There are often dual functions of professional associations, which are membership based such as the AIA in the context of architecture, and licensing bodies ${ }^{76}$ which may have their own requirements for professional credentialing, relating to skills and competence.

\footnotetext{
74 FATF and Egmont Group Report, 'Concealment of Beneficial Ownership' (July 2018), https://www.fatf-gafi.org/ media/fatf/documents/reports/FATF-Egmont-Concealment-beneficial-ownership.pdf (accessed 10 May 2021).

75 ABA, Voluntary Good Practices for Lawyers to Detect and Combat Money Laundering and Terrorist Financing (23 April 2010), https://www.americanbar.org/content/dam/aba/publications/criminaljustice/voluntary_good_ practices_guidance.pdf (accessed 10 May 2021).

76 US Department of Education, 'Professional Licensure', https://sites.ed.gov/international/professional-licensure/ (accessed 10 May 2021).
} 
There needs to be an examination by licensing authorities and/or professional associations in attempts to modify, clarify and create more consistent practice. For professionals that do have ethical codes and licensing requirements, there will be a need to assess how such codes are consistent or inconsistent with the UNGPs. The legal profession has begun such a top-down examination through the work of the IBA, the $\mathrm{ABA}$ and other associations to point out that rules of professional conduct can be interpreted to include a duty to provide advice on human rights.

\section{The Role of Graduate and Professional Education}

Educators across the professions need to continue to push for busines and human rights to be an integral part of education of the professions. Business schools seem to be further along, ${ }^{77}$ with some more specialized fora such as the Principles for Responsible Management Education (PMRE) - which has a working group on business and human rights, recently revived in 2021. PMRE was initially focused more on sustainability and anti-corruption, and not the UNGPs. ${ }^{78}$ There is a Graduate Busines School Network for Business and Human Rights, founded in 2017 by the NYU Stern Center for Business and Human Rights, the Geneva School for Economics and Management, and the Alliance Manchester Business School. ${ }^{79}$

While bar associations are committed to disseminating the UNGPs, law schools do not touch on issues of human rights as part of required classes on professional responsibility. It is unclear to what extent architects learn about human rights as part of their education with at least one academic, the founder of the Centre for Architecture and Human Rights, calling for a reform of the curriculum to encompass human rights. ${ }^{80}$ There is a gap to be filled in graduate and professional education so that the next generation of PSPs understand the idea of respect for human rights, human rights due diligence and identifying harm to rightsholders as part of their bread and butter work. The Business and Human Rights Teaching Forum welcomes all disciplines, and is a useful hub. To date, its members come mainly from law and business schools or from undergraduate education - but other professional services such as architecture, for example, are not actively represented. ${ }^{81}$

\section{Importance of Leverage and Advocacy}

Corporations that have strong human rights policies need to screen their law firms, accountants, architects and others - and ask them to make commitments to the

\footnotetext{
77 Dorothée Baumann-Pauly et al, 'The Case for Business and Human Rights in Business Education - A Tool Kit' (20 November 2020), NYU Stern School of Business (forthcoming), https://ssrn.com/abstract=3741169 or http://dx.doi. org/10.2139/ssrn.3741169 (access 10 May 2021).

78 'PRME Working Group on Business and Human Rights', https://www.unprme.org/prme-working-group-onbusiness-and-human-rights (accessed 10 May 2021). See also notice of relaunch of the working group (19 March 2012), https://www.unprme.org/launch-of-prme-working-group-on-business-and-human-rights (accessed 10 May 2021).

79 https://gbsn.org/gbsn-for-bhr/ (accessed 10 May 2021).

80 Graeme Bristol, Speech: 'Human Rights and Architectural Education', UIA Congress Tokyo 2011, https:// www.researchgate.net/publication/284179613_Human_Rights_and_Architectural_Education (accessed 10 May 2021).

81 Teaching Business and Human Rights Forum website, https://teachbhr.org/ (accessed 10 May 2021).
} 
UNGPs. Leading companies can insist on demonstrable commitments from their advisors. Indeed, the A4ID guide focuses on screening clients as a key place where law firms can examine the human rights commitments of their clients. ${ }^{82}$ Similarly, employees and prospective employees can also exert influence in seeking to work for advisory firms that are rights-respecting. ${ }^{83}$ Civil society groups that focus on business and human rights will also need to turn their attention to PSPs, much as some have done with respect to the role of banks and financial institutions, to show them that indeed there is linkage or more between advice and client human rights abuses. ${ }^{84}$

\section{Conclusion}

None of these strategies will work in isolation. The main message is that in the next decade, it is important to bring the advisors into the UNGP's fold, so that they are not enablers of corporate human right abuses but rather active and strategic problem-solvers who will help to shape stronger corporate respect for human rights. PSPs are trusted experts and gatekeepers. These trusted experts are intimately connected with how a company behaves, performs, and responds to adverse human rights impacts. They need to embed the UNGPs more fully into their internal business models, specifically for when they are rendering advice that on its face is not about human rights. Lawyers are needed to structure deals and write contracts, architects are essential to designing buildings, and management consultants are key to business restructuring. Thus, they are advisors but can also be seen as enablers of human rights abuses or as at least linked to them by virtue of advice that is devoid of a human rights analysis. Similarly, they are gatekeepers in many settings as their professional guidance is required in order for certain approvals and permissions to be granted by the State. This, in turn, translates into leverage, as gatekeepers are necessary conduits for business to operate across the globe.

\footnotetext{
82 A4ID Guide for the Legal Profession, note 58.

83 Editorial, 'Penn Students Must Boycott McKinsey in Light of its Work with ICE', The Daily Pennsylvanian (15 December 2019), https://www.thedp.com/article/2019/12/mckinsey-upenn-consulting-editorial-human-rightsimmigration-ivy-league-philadelphia (accessed 10 May 2021).

84 https://www.banktrack.org/publications (accessed 10 May 2021).
} 